\title{
"THERE CAN BE NO ECOLOGY WITHOUT AN ADEQUATE ANTHROPOLOGY" (LS 118). WHICH MAN CAN TAKE CARE OF OUR COMMON HOME?
}

\begin{abstract}
Introduction
Many have welcomed the publication of the encyclical Laudato si' (24.05.2015) [LS] written by Pope Francis with enthusiasm; this document has been regarded as the point of arrival of a long path Catholic theology has undertaken in the last decades, to face environmental issues.

As a matter of fact, especially from the beginning of the 70s of XXth century, ecological issue has slowly entered as a new topic in both moral doctrine and Christian theology of creation. In the last decades, many studies have accompanied theological reflection on ecology, dealing with environmental issues from different points of view ${ }^{2}$. Gradually, the environmental issue has become part of the theological reflection, both and above all of the moral reflection (human behaviour in the natural environment) and of the theology of creation, encouraged by the environmentalists' stimuli to examine Genesis in more depth, about the stewardship and dominion on the rest of the creatures God entrusts man with. It is known that the starting point of contemporary theology on ecology is linked to the critiques of those accusing Christianity to support, with its doctrine of Creation, a marked anthropocentrism; this one so marked to be considered the responsible for the
\end{abstract}

1 Dr Alberto Piola, Facoltà teologica dell'Italia Settentrionale, Sezione parallela di Torino; mailing address: 10122 Torino, Via XX Settembre, 83, e-mail: donalberto.piola@gmail.com.

2 It is impossible to give an exhaustive bibliography on the topic, given the number of publications on the theme. For a general overview cf. Alexandre Ganoczy, "Prospettive ecologiche della dottrina cristiana della creazione". Concilium 27 (1991): 509-520; Rosino Gibellini, "Il dibattito teologico sull'ecologia". Concilium 31 (1995): 932-944; Antonio Simula, In pace con il creato. Chiesa cattolica ed ecologia (Padova, 2001), especially chapter 1; Simone Morandini, Teologia ed ecologia (Brescia, 2005), 13-116; Francesco Conigliaro, "Ecologia e teologia". In: Etica pubblica ed ecologia, ed. by Gian Luigi Brena, (Padova, 2005), 47-103; Olivier Landron, Le catholicisme vert. Histoire des relations entre l'Église et la nature au XXe siècle (Paris, 2008); Alberto Piola, "Custodire il creato: prospettive nella teologia sistematica". La Scuola Cattolica 143 (2015): 119-142; Gianni Colzani, "La questione ambientale. Implicazioni teologiche". La Rivista del Clero Italiano 97 (2016): 205-225. For a general overview on the papal magisterium prior to LS cf. Federico Badiali, "La custodia del creato nel recente magistero pontificio". Rivista di Teologia dell'Evangelizzazione 18 (2014): 297-322; Michael Czerny, Bernd Hagenkord, Antonio Spadaro, “"Custodire l'intera creazione». Un servizio del vescovo di Roma”. In: Francis, Laudato si'. Lettera enciclica sulla cura della casa comune. Testo integrale e commento de "La Civiltà Cattolica". Introduzione di Antonio Spadaro, (Milano, 2015), 137-152. 
environmental crisis, when technology let us have dominion over the environment, which proved fatal ${ }^{3}$.

This study intends to analyse the link between anthropology and ecology; it is one of the underlying themes in LS, in which we read at n. 118: "there can be no ecology without an adequate anthropology,. Our question, therefore, is: which man is 'adequate, to take care of 'our common home, where the human family lives? Which man is faithful to God's creative intent and is therefore able not only of fraternity towards the other men but of a 'universal fraternity, (LS 228) with all the Creation?

It is a huge subject, concerning many aspects of man's behaviours towards the environment; here, the main aim is to underline the close link between ecology and anthropology, stated in chapter 3 of the encyclical ('The human roots of the ecological crisis,). This link is not a real novelty of LS; Pope John Paul II already linked the anthropological issue to an 'anthropologic error:

In his desire to have and to enjoy rather than to be and to grow, man consumes the resources of the earth and his own life in an excessive and disordered way. At the root of the senseless destruction of the natural environment lies an anthropological error, which unfortunately is widespread in our day. Man, who discovers his capacity to transform and in a certain sense create the world through his own work, forgets that this is always based on God's prior and original gift of the things that are. Man thinks that he can make arbitrary use of the earth, subjecting it without restraint to his will, as though it did not have its own requisites and a prior God-given purpose, which man can indeed develop but must not betray. Instead of carrying out his role as a co-operator with God in the work of creation, man sets himself up in place of God and thus ends up provoking a rebellion on the part of nature, which is more tyrannized than governed by him. ${ }^{4}$

In all this, one notes first the poverty or narrowness of man's outlook, motivated as he is by a desire to possess things rather than to relate them to the truth, and lacking that disinterested, unselfish and aesthetic attitude that is born of wonder in the presence of being and of the beauty which enables one to see in visible things the message of the invisible God who created them. In this regard, humanity today must be conscious of its duties and obligations towards future generations. ${ }^{5}$

This study wants to underline that one of the most important contributions of the ecological magisterium of Pope Francis is indeed this invitation to meditate on modern anthropocentrism, which risks to be a 'tyrannical anthropocentrism, (LS 68), 'distorted, misguided, (LS 69; 118) one which 'leads to a misguided lifestyle, (LS 122); thanks to this study it will be easier to understand the call for the 'ecological conversion, (cf. LS 216-221) the encyclical contains.

3 We can remember among the others Lynn White, “The Historical Roots of our Ecological Crisis". Science 3767 (1967): 1202-1207.

4 Encyclical Letter Sollicitudo Rei Socialis, 34: loc. cit., 559f.; Message for the 1990 World Day of Peace: Acta Apostolicae Sedis 82 (1990): 147-156, access 09.06.2016, http://w2.vatican.va/content/john-paul-ii/en/encyclicals/documents/hf_jp-ii_enc_01051991_centesimus-annus.html-\%2424.

5 John Paul II, Encyclical Letter Centesimus Annus (01.05.1991), 37. 


\section{1. 'Everything is connected, (LS 117): the close link between man and environment}

The entire document is pervaded by a question: 'What kind of world do we want to leave to those who come after us, to children who are now growing up?; the Pope explains that this question not only concerns the environment in isolation; the issue cannot be approached piecemeal. When we ask ourselves what kind of world we want to leave behind, we think in the first place of its general direction, its meaning and its values. Unless we struggle with these deeper issues, I do not believe that our concern for ecology will produce significant results. But if these issues are courageously faced, we are led inexorably to ask other pointed questions: What is the purpose of our life in this world? Why are we here? What is the goal of our work and all our efforts? What need does the earth have of us? It is no longer enough, then, simply to state that we should be concerned for future generations. We need to see that what is at stake is our own dignity. (LS 160)

Ecology is also a matter of anthropological questions, asking man to reveal his identity. In the encyclical, 'integral ecology becomes the model to keep environmental phenomena and problems (global warming, pollution, resource depilation, deforestation etc) together with issues not normally associated with ecology in the strict sense, such as livability, beauty of urban spaces or the overcrowding on public transports. Moreover, this attention to connections and relationships allows us to read the relationship with our body through integral ecology (n. 155), or social and institutional dynamics at all levels ${ }^{6}$. Ecological and social problems are not put on different levels, but they are one single problem:

It is essential to seek comprehensive solutions which consider the interactions within natural systems themselves and with social systems. We are faced not with two separate crises, one environmental and the other social, but rather with one complex crisis which is both social and environmental. Strategies for a solution demand an integrated approach to combating poverty, restoring dignity to the excluded, and at the same time protecting nature. (LS 139)

Therefore, Pope Francis doesn't only describe ecological phenomena, but he also looks at all the complex net of relationships present in our common home, since

everything is connected. Once the human being declares independence from reality and behaves with absolute dominion, the very foundations of our life begin to crumble, for "instead of carrying out his role as a cooperator with God in the work of creation, man sets himself up in place of God and thus ends up provoking a rebellion on the part of nature" (LS 117)

This relationship between anthropology and ecology is absolutely one of the most important topics of the encyclical and it also becomes an hermeneutical key to understand some key-concepts on which we can base our action to save 'our common home:

6 Giacomo Costa, Paolo Foglizzo, “L'ecologia integrale/1 - Un paradigma concettuale”, access 27.06.2015, http:// www.aggiornamentisociali.it/easyne2/LYT.aspx?Code=AGSO\&IDLYT=769\&ST=SQL\&SQL=ID_Documento $=12736$.

7 John Paul II, Encyclical Letter Centesimus Annus (1 May 1991), 37: Acta Apostolicae Sedis 83 (1991): 840. 
- The proposal of 'integral ecology, a concept developed in chapter 4, useful to state the connections in the environment (man included) and therefore all human and social dimensions of the common home (cf. LS 137-138). It is necessary to find solutions to social and environmental problems, taking into consideration those bonds; this requires a 'cultural revolution:

All of this shows the urgent need for us to move forward in a bold cultural revolution. Science and technology are not neutral; from the beginning to the end of a process, various intentions and possibilities are in play and can take on distinct shapes. Nobody is suggesting a return to the Stone Age, but we do need to slow down and look at reality in a different way, to appropriate the positive and sustainable progress which has been made, but also to recover the values and the great goals swept away by our unrestrained delusions of grandeur (LS 114);

- The earth is a gift of God, and this has a clear anthropological significance because we are not God. The earth was here before us and it has been given to us. This allows us to respond to the charge that Judaeo-Christian thinking, on the basis of the Genesis account which grants man "dominion" over the earth (cf. Gen 1:28), has encouraged the unbridled exploitation of nature by painting him as domineering and destructive by nature. This is not a correct interpretation of the Bible as understood by the Church. Although it is true that we Christians have at times incorrectly interpreted the Scriptures, nowadays we must forcefully reject the notion that our being created in God's image and given dominion over the earth justifies absolute domination over other creatures. The biblical texts are to be read in their context, with an appropriate hermeneutic, recognizing that they tell us to "till and keep" the garden of the world (cf. Gen 2:15) (LS 67);

- Hence, the earth is a gift to keep: the meaning of this term is explained in the chapter analysing the biblical doctrine of Creation:

"Tilling" refers to cultivating, ploughing or working, while "keeping" means caring, protecting, overseeing and preserving. This implies a relationship of mutual responsibility between human beings and nature. Each community can take from the bounty of the earth whatever it needs for subsistence, but it also has the duty to protect the earth and to ensure its fruitfulness for coming generations. "The earth is the Lord's" (Ps 24:1); to him belongs "the earth with all that is within it" (Dt 10:14). Thus God rejects every claim to absolute ownership: "The land shall not be sold in perpetuity, for the land is mine; for you are strangers and sojourners with me" (Lev 25:23). (LS 67)

A reciprocal relationship arises between man and earth, inside the necessary ecological conversion which is essential for Christian commitment:

the ecological crisis is also a summons to profound interior conversion. It must be said that some committed and prayerful Christians, with the excuse of realism and pragmatism, tend to ridicule expressions of concern for the environment. Others are passive; they choose not to change their habits and thus become inconsistent. So what they all need is an "ecological conversion", whereby the effects of their encounter with Jesus Christ become evident in their relationship with the world around them. Living our vocation to be protec- 
tors of God's handiwork is essential to a life of virtue; it is not an optional or a secondary aspect of our Christian experience. (LS 217)

After the publication of LS, Pope Francis has spoken again about the link between ecology and anthropology ${ }^{8}$ :

- in his speech to the Environment Ministers of the European Union (16.09.2015), reminding them that 'the environment is a collective heritage of all humanity, and each of us is responsible for it, he declared that today 'on the one hand science and technology places unprecedented power in our hands; on the other, the proper use of this power requires us to adopt a more integral and inclusive vision";

- in his speech to US Congress (24.09.2015), reminding them that the environmental challenge concerns all people, he renewed the invitation of LS to 'redirect our steps, (LS 61) and he urged USA to take courageous actions 'to avert the most serious effects of the environmental deterioration caused by human activity,. These actions are possible because man has the necessary freedom to limit and direct technology (cf. LS 112) and therefore to work hard "«at the service of another type of progress, one which is healthier, more human, more social, more integral» (LS 112) ${ }^{10}$;

- in his speech at UN (25.09.2015) he stated that in our global world there are broad sectors which are vulnerable, victims of power badly exercised: for example, the natural environment and the vast ranks of the excluded. These sectors are closely interconnected and made increasingly fragile by dominant political and economic relationships. That is why their rights must be forcefully affirmed, by working to protect the environment and by putting an end to exclusion.

The defense of a 'right of the environment, arises from the fact that man too is a part of the environment and for Christians, as well as for believers of other monotheistic religions, he originates out of Creator's own decision of love; this allows man to use the Creation but 'he is not authorized to abuse it, much less to destroy it,. Francis was calling on all, and especially on international rulers, to work hard for an 'integral human development' through 'a will which is effective, practical and constant, concrete steps and immediate measures for preserving and improving the natural environment and thus putting an end as quickly as possible to the phenomenon of social and economic exclusion, with its baneful consequences ${ }^{11}$;

8 Cf. Fernando Chica Arellano, "Ecología y cristianismo. Esbozo de algunas reflexiones de estos 50 años a la luz del magisterio del papa Francisco". Anales Valentinos Nueva Serie 2 (2015): 305-328. It is also necessary to point out that in his LS Pope Francis has expanded some ideas of the speeches he gave during the Wednesday general audiences in St Peter Square, in particular on 05.06.2013 and on 21.05.2014; he had discussed about ecology during other occasions, particularly in his speech at European Parliament (Strasbourg, 25.11.2014) and in his Joint Declaration signed with Patriarch Bartholomew I (Jerusalem, 30.11.2014).

9 “Address of his holiness Pope Francis to the Environment Ministers of the European Union", access 16.05.2016, http://w2.vatican.va/content/francesco/en/speeches/2015/september/documents/papa-francesco_20150916_ministri-ambiente-unione-europea.html.

10 "Address of Holy Father to the Joint Session of the United States Congress", access 16.05.2016, http://w2.vatican. $\mathrm{va} /$ content/francesco/en/speeches/2015/september/documents/papa-francesco_20150924_usa-us-congress.html.

11 "Meeting with the members of the General Assembly of the United Nations Organization", access 16.05.2016, http://w2.vatican.va/content/francesco/en/speeches/2015/september/documents/papa-francesco_20150925_onuvisita.html. 
- in his post-synodal apostolic exhortation Amoris laetitia (19.03.2016) he spoke about the social degeneration brought about by sin, as, for example, when human beings tyrannize nature, selfishly and even brutally ravaging it. (n. 26)

\section{Man: not a tyrant but the custodian of the Creation}

The deepest root of Pope Francis's calls can be found on the anthropological level. The Cristian proposal for ecology can be summarized in one of the concise thesis the encyclical is full of: 'there can be no ecology without an adequate anthropology, (LS 118). Pope Francis's statements are clear:

It would hardly be helpful to describe symptoms without acknowledging the human origins of the ecological crisis. A certain way of understanding human life and activity has gone awry, to the serious detriment of the world around us. Should we not pause and consider this? At this stage, I propose that we focus on the dominant technocratic paradigm and the place of human beings and of human action in the world. (LS 101)

Chapter 3 is entirely dedicated to analyse the human root of the ecological crisis, particularly through the critique against 'technocratic paradigm, which aims at possessing nature as an object.

Francis recognises the undeniable advances reached by humanity, thanks to technological developments ${ }^{12}$. Nonetheless, he also recognises the risks of a progress not subject to the judgement of conscience:

104. Yet it must also be recognized that nuclear energy, biotechnology, information technology, knowledge of our DNA, and many other abilities which we have acquired, have given us tremendous power. (...) Never has humanity had such power over itself, yet nothing ensures that it will be used wisely, particularly when we consider how it is currently being used.

105. There is a tendency to believe that every increase in power means "an increase of "progress' itself", an advance in "security, usefulness, welfare and vigour; ... an assimilation of new values into the stream of culture"13, as if reality, goodness and truth automatically flow from technological and economic power as such. The fact is that "contemporary man has not been trained to use power well", [Ibid.] because our immense technological development has not been accompanied by a development in human responsibility, values and conscience. (...) In this sense, we stand naked and exposed in the face of our everincreasing power, lacking the wherewithal to control it. We have certain superficial mecha-

12 'Technology itself «expresses the inner tension that impels man gradually to overcome material limitations». [Benedict XVI, Encyclical Letter Caritas in Veritate (29 June 2009), 69: Acta Apostolicae Sedis 101 (2009): 702] Technology has remedied countless evils which used to harm and limit human beings. 103. Technoscience, when well directed, can produce important means of improving the quality of human life, from useful domestic appliances to great transportation systems, bridges, buildings and public spaces. It can also produce art and enable men and women immersed in the material world to "leap" into the world of beauty, (LS 102.103).

13 Romano Guardini, Das Ende der Neuzeit, Würzburg, 1965', 87 (English: The End of the Modern World (Wilmington, 1998), 82). 
nisms, but we cannot claim to have a sound ethics, a culture and spirituality genuinely capable of setting limits and teaching clear-minded self-restraint. (LS 104.105)

The excess of anthropocentrism of modernity lies at the root of it (cf. LS 116). Due to it, mankind has become self-referential, whose logic is that of a 'throwaway' culture 'which legitimises every waste, environmental or human, which treats nature and other living creatures as mere objects, and leads to countless forms of dominion. The human root of ecological crisis lies therefore in human freedom, which can choose a tyrannical anthropocentrism (cf. LS 68) ${ }^{14}$.

Francis recognises the deep root of the problem:

It is as if the subject were to find itself in the presence of something formless, completely open to manipulation. Men and women have constantly intervened in nature, but for a long time this meant being in tune with and respecting the possibilities offered by the things themselves. It was a matter of receiving what nature itself allowed, as if from its own hand. Now, by contrast, we are the ones to lay our hands on things, attempting to extract everything possible from them while frequently ignoring or forgetting the reality in front of us. Human beings and material objects no longer extend a friendly hand to one another; the relationship has become confrontational. This has made it easy to accept the idea of infinite or unlimited growth, which proves so attractive to economists, financiers and experts in technology. It is based on the lie that there is an infinite supply of the earth's goods, and this leads to the planet being squeezed dry beyond every limit. (LS 106)

Environmental degradation:

is just one sign of a reductionism which affects every aspect of human and social life. We have to accept that technological products are not neutral, for they create a framework which ends up conditioning lifestyles and shaping social possibilities along the lines dictated by the interests of certain powerful groups. Decisions which may seem purely instrumental are in reality decisions about the kind of society we want to build. (LS 107)

Against 'technocratic paradigm, Francis calls for an 'ecological conversion, (LS 217): Ecological culture cannot be reduced to a series of urgent and partial responses to the immediate problems of pollution, environmental decay and the depletion of natural resources. There needs to be a distinctive way of looking at things, a way of thinking, policies, an educational programme, a lifestyle and a spirituality which together generate resistance to the assault of the technocratic paradigm. (LS 111)

The role of human freedom is therefore central:

We are free to apply our intelligence towards things evolving positively, or towards adding new ills, new causes of suffering and real setbacks. (LS 79)

Man has in himself the ability to overcome the technocratic paradigm, to carry out 'a bold cultural revolution, 'to recover the values and the great goals swept away by our unrestrained delusions of grandeur' (LS 114). It is necessary to meditate - that is what the title of chapter 3 (nos. 115-136) suggests - on 'The crisis and effects of modern anthropo-

14 Cf. Miguel Rubio, “Laudato si’: Una teología de la creación en perspectiva ecológica”. Moralia 39 (2016): 89-117. 
centrism,: today, technical thought is prized over reality (cf. LS 115), hence it is a matter of great urgency to regain our contact with reality and its limits:

this in turn is the condition for a more sound and fruitful development of individuals and society. (LS 116)

The damages to the ecosystem and the indifference to the environmental impact are only the most striking sign of a disregard for the message contained in the structures of nature itself. When we fail to acknowledge as part of reality the worth of a poor person, a human embryo, a person with disabilities - to offer just a few examples - it becomes difficult to hear the cry of nature itself; everything is connected. Once the human being declares independence from reality and behaves with absolute dominion, the very foundations of our life begin to crumble, for "instead of carrying out his role as a cooperator with God in the work of creation, man sets himself up in place of God and thus ends up provoking a rebellion on the part of nature"15.

118. This situation has led to a constant schizophrenia, wherein a technocracy which sees no intrinsic value in lesser beings coexists with the other extreme, which sees no special value in human beings. But one cannot prescient from humanity. There can be no renewal of our relationship with nature without a renewal of humanity itself. There can be no ecology without an adequate anthropology. (LS 117-118)

Christian anthropology is the answer to the modern crisis:

If the present ecological crisis is one small sign of the ethical, cultural and spiritual crisis of modernity, we cannot presume to heal our relationship with nature and the environment without healing all fundamental human relationships. Christian thought sees human beings as possessing a particular dignity above other creatures; it thus inculcates esteem for each person and respect for others. Our openness to others, each of whom is a "thou" capable of knowing, loving and entering into dialogue, remains the source of our nobility as human persons. A correct relationship with the created world demands that we not weaken this social dimension of openness to others, much less the transcendent dimension of our openness to the "Thou" of God. Our relationship with the environment can never be isolated from our relationship with others and with God. (LS 119)

The anthropologic error to be challenged is the risk of individualism, typical of postmodern culture. That means, man is unable to see himself as part of the cosmic fraternity (already mentioned by St. Francis of Assisi in his Canticle of the Sun): there is

an ethical and cultural decline which has accompanied the deterioration of the environment. Men and women of our postmodern world run the risk of rampant individualism, and many problems of society are connected with today's self-centred culture of instant gratification. We see this in the crisis of family and social ties and the difficulties of recognizing the other. Parents can be prone to impulsive and wasteful consumption, which then affects their children who find it increasingly difficult to acquire a home of their own and build a family. Furthermore, our inability to think seriously about future generations is linked to our inability to broaden the scope of our present interests and to give consideration to

15 John Paul II, Encyclical Letter Centesimus Annus (1 May 1991), 37: Acta Apostolicae Sedis 83 (1991): 840. 
those who remain excluded from development. Let us not only keep the poor of the future in mind, but also today's poor, whose life on this earth is brief and who cannot keep on waiting. Hence, "in addition to a fairer sense of intergenerational solidarity there is also an urgent moral need for a renewed sense of intergenerational solidarity"16. (LS 162)

Here one can find concrete condemnation of man's excessive enjoyment and use of the creation; 'it means to reach conscience of individual responsibility towards environment, based on the awareness of the inseparable link between authentic human fulfilment and stewardship of the Creation, to allow future generations to benefit from it, so that they too could have the same pitch to compete for their worldly match ${ }^{17}$.

\section{For an anthropology open to the care of our common home}

LS presents therefore a meditation on the biblical task of 'stewardship' entrusted to man; a task based on the awareness of being one single human family, sharing 'our common home', and based on fraternity linking all human beings:

called into being by one Father, all of us are linked by unseen bonds and together form a kind of universal family, a sublime communion which fills us with a sacred, affectionate and humble respect. (LS 89)

Pope Francis had already called to 'care, in his homily for the inauguration of his Pontificate (19.03.2013), commenting on the figure of Saint Joseph:

The vocation of being a "protector", however, is not just something involving us Christians alone; it also has a prior dimension which is simply human, involving everyone. It means protecting all creation, the beauty of the created world, as the Book of Genesis tells us and as Saint Francis of Assisi showed us. It means respecting each of God's creatures and respecting the environment in which we live. (...) Please, I would like to ask all those who have positions of responsibility in economic, political and social life, and all men and women of goodwill: let us be "protectors" of creation, protectors of God's plan inscribed in nature, protectors of one another and of the environment. Let us not allow omens of destruction and death to accompany the advance of this world!

What we need is a man who has understood the task of 'taking care, for the stewardship of our common home. It entails a stewardship concerning not only man but all the Creation, called to a 'universal fraternity, recognising the gratuitousness of the gift:

Jesus reminded us that we have God as our common Father and that this makes us brothers and sisters. Fraternal love can only be gratuitous; it can never be a means of repaying others for what they have done or will do for us. That is why it is possible to love our enemies. This same gratuitousness inspires us to love and accept the wind, the sun and the clouds, even though we cannot control them. In this sense, we can speak of a "universal fraternity". (LS 228)

16 Benedict XVI, Message for the 2010 World Day of Peace, 8: Acta Apostolicae Sedis 102 (2010): 45.

17 Lucio Franzese, “Laudato si': il superamento dell'individualismo”. La Società 23, 3 (2015), 147. 
Pope Francis's reflection does not want to enter the theological debate, but rather to call for action since the stewardship of our common home is linked to man's responsible action $^{18}$. It is man's responsibility to promote and cooperate for a 'sustainable and integral, development; Pope Francis applies to ecology his thesis of "globalization of indifference", firstly introduced during his apostolic journey to Lampedusa, in order to confront a lack of fraternity and awareness to belong to a single human family:

We need to strengthen the conviction that we are one single human family. There are no frontiers or barriers, political or social, behind which we can hide, still less is there room for the globalization of indifference. (LS 52)

If man has understood his true identity, presented by the biblical message, he can not separate his relationships with the earth from those towards his neighbour: this will prove a great anthropologic error, as demonstrated by the creation accounts in the Genesis, particularly Noah's one ${ }^{19}$.

Therefore, the meditation in LS on the link between anthropology and ecology represents a development of previous interventions of the magisterium, which had already invited to talk about biblical anthropocentrism, in a softened way ${ }^{20}$ : man is the apex of God's creation, but he is nonetheless a creature (as stated by John Paul II in his Sollicitudo rei socialis 2921); God's biblical command to take dominion must be read inside man's creation in God's image and likeness, with no references or risk of any Promethean drift. On the contrary, it asks to take into consideration man's duties towards natural environment ${ }^{22}$. If the first accusations made by the environmentalists against Christianity concerned the responsibility of the biblical message in promoting a dangerous anthropology for the environment, now it has become clear that we must correctly

18 'The urgent challenge to protect our common home includes a concern to bring the whole human family together to seek a sustainable and integral development, for we know that things can change. The Creator does not abandon us; he never forsakes his loving plan or repents of having created us. Humanity still has the ability to work together in building our common home. Here I want to recognize, encourage and thank all those striving in countless ways to guarantee the protection of the home which we share (LS 13).

19 'Disregard for the duty to cultivate and maintain a proper relationship with my neighbour, for whose care and custody I am responsible, ruins my relationship with my own self, with others, with God and with the earth. When all these relationships are neglected, when justice no longer dwells in the land, the Bible tells us that life itself is endangered. We see this in the story of Noah, where God threatens to do away with humanity because of its constant failure to fulfil the requirements of justice and peace: «I have determined to make an end of all flesh; for the earth is filled with violence through them» (Gen 6:13). These ancient stories, full of symbolism, bear witness to a conviction which we today share, that everything is interconnected, and that genuine care for our own lives and our relationships with nature is inseparable from fraternity, justice and faithfulness to others (LS 70).

20 Cf. Badiali, "La custodia del creato", 300-306.

21 To reach and obtain a real development we need to remember man's true nature; he is created in God's image and in his likeness, but he has 'a bodily and a spiritual nature, symbolized in the second creation account by the two elements: the earth, from which God forms man's body, and the breath of life which he breathes into man's nostrils (cf. Gen 2:7). Thus man comes to have a certain affinity with other creatures: he is called to use them, and to be involved with them. As the Genesis account says (cf. Gen 2:15), he is placed in the garden with the duty of cultivating and watching over it, being superior to the other creatures placed by God under his dominion (cf. Gen 1:25-26). But at the same time man must remain subject to the will of God, who imposes limits upon his use and dominion over things (cf. Gen 2:16-17), just as he promises his mortality (cf. Gen 2:9; Wis 2:23).

22 Cf. Benedict XVI, Encyclical Letter Caritas in veritate (29.06.2009) 48. 
confront the two tasks God's entrusted man with in the two creation accounts: 'have dominion, and 'take care,.

Which man can therefore take care of 'our common home,? LS provides us with two contributions: firstly, it shows which man must not carry out the task of stewardship, through a strict critique against a distorted anthropocentrism resulting from the technocratic paradigm which reveals itself in the economistic-financial paradigm ${ }^{23}$; secondly, it offers - especially in chapter 6 - ecological education and spirituality, which outline the virtues man should have to be able to take care. Those virtues may be summarized in 'ecological equilibrium, on different levels:

establishing harmony within ourselves, with others, with nature and other living creatures, and with God. Environmental education should facilitate making the leap towards the transcendent which gives ecological ethics its deepest meaning. (LS 210)

These words are much more than just technical answers to environmental issues: technical answers alone are not enough, what we need to realize is the anthropologic core of the ecologic crisis. Ecologic conversion is therefore an anthropological conversion: solution does not lie in an extreme biocentrism, leading to the "revenge" of nature over man; on the contrary, understanding that "everything is connected, is central, together with the notion that environmental and human ethic degradations are strictly linked ${ }^{24}$. According to a thesis Pope Francis had already presented in his Evangelii gaudium 53, this involves reacting against a 'throwaway culture, which makes us discard both things and human beings (cf. LS 22). At this point, we have better understood the anthropological significance of the 'integral ecology, in contrast with the technocratic paradigm and the pervasiveness of technology $y^{25}$ : it is an ecology which does not need to choose in the false dilemma between the primacy of nature (biocentrism) or primacy of the person (anthropocentrism) ${ }^{26}$, but it calls for a 'conversion, centered on the Creator; looking at God one finds man's and nature's true identities ('an authentic humanity', LS 112) and one understands that the 'universal fraternity, calls for the creation of an alliance, a pact between man and environment (cf. LS 209-215). It is from this point of view that many appeals for action and change arise from the encyclical.

\section{Conclusion}

LS broadens the "frontiers" of anthropology and indeed of Christian commitment to ecological issue, showing the close link between ecology and anthropology, going beyond the accusations against the Church, as the responsible of the ecologic crisis caused by an

23 Cf. Luciano Valle, Papa Francesco e l'ambiente. Percorsi sulla teologia della Creazione dai Padri della Chiesa alla Laudato si' (Pavia, 2015), 214-220.

24 Even before LS, the Italian theologian Pierangelo Sequeri said that we need a redemption 'from the failure of dominion and stewardship entrusted to man, corrupted in his arrogance of supremacy and dominion and the destruction of the gift (Custode, non tiranno. Per un nuovo rapporto fra persona e creato [Bologna, 2014], 24).

25 Cf. Leopoldo Sandonà, “La terra ci precede. Le sfide generative dell'ecologia umana”. Nuova umanità 37 (2015): 470.

26 Cf. Luigi Alici, "Natura e persona: lo "sguardo diverso" di papa Francesco". In: Abiterai la terra. Commento all'enciclica Laudato si', ed. by Giuseppe Notarstefano (Roma, 2015), 51-58. 
anthropological error. According to Pope Francis ecology does not only need technology, but it also needs contemplation, to remember the constitutive relationality of the per$\operatorname{son}^{27}$ : this is the true contribution Christian faith can offer the ecological debate, taking St Francis of Assisi's message for our world; LS explained us that this message, reread at the beginning of the XXIth century, encourages us towards an 'integral ecology, which 'calls for openness to categories which transcend the language of mathematics and biology, and take us to the heart of what it is to be human (LS 11).

\section{Bibliography}

Alici, Luigi. "Natura e persona: lo «sguardo diverso» di papa Francesco". In: Abiterai la terra. Commento all'enciclica "Laudato si'”, ed. by Giuseppe Notarstefano, 51-58. Roma 2015.

Badiali, Federico. "La custodia del creato nel recente magistero pontificio". Rivista di Teologia dell'Evangelizzazione 18 (2014): 297-322.

Bruni, Luigino. "Accanto a Lazzaro. Custodire la terra come profezia senza demonizzazioni". Il Regno - Attualità 60 (2015): 437-438.

Bruni, Luigino. "L'umanesimo della gratuità". Nuova umanità 37 (2015): 435-447.

Chica, Arellano, Fernando. "Ecología y cristianismo. Esbozo de algunas reflexiones de estos 50 años a la luz del magisterio del papa Francisco". Anales Valentinos Nueva Serie 2 (2015): 305-328.

Colzani, Gianni. "La questione ambientale. Implicazioni teologiche". La Rivista del Clero Italiano 97 (2016): 205-225.

Conigliaro, Francesco. "Ecologia e teologia". In: Etica pubblica ed ecologia, ed. by Gian Luigi Brena, 47-103. Padova, 2005.

Costa, Giacomo, Paolo Foglizzo. “«Laudato si'»: un'enciclica poliedro”. Rivista del Clero Italiano 96 (2015): 485-496.

Costa, Giacomo, Paolo Foglizzo. "L'ecologia integrale/1 - Un paradigma concettuale". Access 27.06.2015. http://www.aggiornamentisociali.it/easyne2/LYT. aspx?Code=AGSO\&IDLYT=769\&ST=SQL\&SQL=ID_Documento=12736.

Czerny, Michael, Bernd Hagenkord, Antonio Spadaro. "«Custodire l'intera creazione». Un servizio del vescovo di Roma". In: Francis, Laudato si'. Lettera enciclica sulla cura della casa comune. Testo integrale e commento de "La Civiltà Cattolica". Introduzione di Antonio Spadaro, 137-152. Milano, 2015.

Francis. "Address of his holiness Pope Francis to the Environment Ministers of the European Union". Access 16.05.2016. http://w2.vatican.va/content/francesco/en/speeches/2015/september/documents/papa-francesco_20150916_ministri-ambiente-unione-europea.html.

Francis. "Address of Holy Father to the Joint Session of the United States Congress". Access 16.05.2016. http://w2.vatican.va/content/francesco/en/speeches/2015/september/documents/papa-francesco_20150924_usa-us-congress.html.

27 Cf. Mauro Magatti, “Ecologia umana. L'essere umano è relazione”. Rivista del Clero Italiano 96 (2015): 499 and 502 . 
Francis. "Meeting with the members of the General Assembly of the United Nations Organization". Access 16.05.2016. http://w2.vatican.va/content/francesco/en/speeches/2015/ september/documents/papa-francesco_20150925_onu-visita.html.

Franzese, Lucio. "Laudato si': il superamento dell'individualismo". La Società 23, 3 (2015): 144-149.

Ganoczy, Alexandre. "Prospettive ecologiche della dottrina cristiana della creazione". Concilium 27 (1991): 509-520.

Gibellini, Rosino. "Il dibattito teologico sull'ecologia”. Concilium 31 (1995): 932-944.

Gronchi, Maurizio. "Le vie nuove indicate dall'enciclica di Papa Francesco. Un progetto di ecologia integrale". L'Osservatore Romano: 19.06.2015.

Landron, Olivier. Le catholicisme vert. Histoire des relations entre l'Église et la nature au XXe siècle. Paris, 2008.

Magatti, Mauro. "Ecologia umana. L'essere umano è relazione". Rivista del Clero Italiano 96 (2015): 497-505.

Morandini, Simone. Teologia ed ecologia (Brescia, 2005), 13-116.

Notarstefano, Giuseppe. "Laudato si': il paradigma dell'ecologia integrale". La Società 23 (2015), nr 3: 150-155.

Piola, Alberto. "Custodire il creato: prospettive nella teologia sistematica". La Scuola Cattolica 143 (2015): 119-142.

Rubio, Miguel. "Laudato si': Una teología de la creación en perspectiva ecológica”. Moralia 39 (2016): 89-117.

Sandonà, Leopoldo. "La terra ci precede. Le sfide generative dell'ecologia umana". Nuova umanità 37 (2015): 463-475.

Sequeri, Pierangelo. Custode, non tiranno. Per un nuovo rapporto fra persona e creato. Bologna, 2014.

Simula, Antonio. In pace con il creato. Chiesa cattolica ed ecologia). Padova, 2001.

Valle, Luciano. Papa Francesco e l'ambiente. Percorsi sulla teologia della Creazione dai Padri della Chiesa alla Laudato si'. Pavia, 2015.

White, Lynn. “The Historical Roots of our Ecological Crisis". Science 3767 (1967): 1202-1207.

\begin{abstract}
One of the underlying thesis of Laudato si' is the close link between anthropology and ecology. Pope Francis calls for an ecological conversion, which involves an adequate anthropology based on an authentic interpretation of man's creation in God's likeness. Only the man who sees himself and acts as guardian, and not as a tyrant, can take care of our common home.
\end{abstract}

Keywords: Laudato si', ecology, anthropology 


\section{Streszczenie}

\section{„NIE MA EKOLOGII BEZ WLAŚCIWEJ ANTROPOLOGII” (LS 118). JAKI CZŁOWIEK MOŻE ZATROSZCZYĆ SIĘ O NASZ WSPÓLNY DOM?}

Jedną z najważniejszych tez encykliki Laudato si' jest ścisły związek pomiędzy antropologią i ekologią. Papież Franciszek wzywa do ekologicznego nawrócenia, które wiąże się z właściwą antropologią opartą na autentycznej interpretacji stworzenia człowieka na obraz Boga. Tylko człowiek, który postrzega samego siebie i działa jako strażnik, a nie jako tyran, może zaopiekować się naszym wspólnym domem.

Słowa kluczowe: Laudato si', ekologia, antropologia 